\title{
ANALISIS EFEKTIVITAS DAN KONTRIBUSI PAJAK BPHTB TERHADAP PENERIMAAN PAJAK DAERAH KOTA MANADO
}

\author{
Oleh: \\ Hendrik Ricart Pangemanan \\ Inggriani Elim \\ Stanley Kho Walandouw \\ Fakultas Ekonomi dan Bisnis, Jurusan Akuntansi \\ Universitas Sam Ratulangi Manado \\ email: ricart_hendrik@yahoo.co.id
}

\begin{abstract}
ABSTRAK
Pajak Daerah merupakan salah satu sumber pembiayaan pembangunan daerah yang sangat diandalkan guna mendukung pelaksanaan otonomi daerah. Salah satu jenis Pajak Daerah yang dipungut oleh Pemerintah Kota adalah Pajak Bea Perolehan Hak atas Tanah dan Bangunan (BPHTB). Pajak BPHTB adalah pajak atas perolehan hak atas tanah dan/atau bangunan. Penelitian ini bertujuan untuk mengetahui tingkat efektivitas dan kontribusi Pajak BPHTB terhadap penerimaan Pajak Daerah Kota Manado. Penelitian ini dilakukan pada Dinas Pendapatan Kota Manado. Metode analisis yang digunakan adalah metode deskriptif kuantitatif, yaitu menganalisis data target dan realisasi penerimaan Pajak BPHTB tahun 2011 dan 2012 dengan menggunakan rasio efektivitas dan rasio kontribusi. Hasil penelitian menunjukkan bahwa tingkat efektivitas Pajak BPHTB tahun 2011 belum mencapai target, sebab hanya mencapai 70,99\% dan pada tahun 2012 sudah mencapai target dengan persentase $116,95 \%$ yang termasuk dalam kriteria sangat efektif. Dalam kurun waktu 2 tahun terakhir sejak dialihkan menjadi Pajak Daerah tahun 2011, kontribusi Pajak BPHTB menunjukkan kriteria kontribusi yang cukup baik terhadap penerimaan Pajak Daerah tahun 2011 dan 2012. Tahun 2011 persentase kontribusinya sebesar 30,25\% dan tahun 2012 naik menjadi 30,72\%.
\end{abstract}

Kata kunci : pajak bphtb, pajak daerah, efektivitas,kontribusi

\begin{abstract}
Local Taxes are one source of financing local development a very reliable to support the implementation of regional autonomy. One type of regional tax levied by the City Government is Customs on Acquisition of Land and Building (BPHTB). BPHTB tax is a tax on acquisition of land and / or buildings. This study aims to determine the effectiveness and contribution of BPHTB tax to the revenue of Manado City Local Tax. The research was conducted at the Department of Revenue the city of Manado. Method of analysis used is descriptive quantitative method, namely analyzing the data of the target and realization receipts of BPHTB Tax in 2011 and 2012 by using the ratio of effectiveness and contribution ratio. The results showed that the rate of effectiveness BPHTB Tax in 2011 has not reached the target, because only reached $70.99 \%$ and in 2012 already reached the target with the percentage $116.95 \%$ which is included in the criteria is very effective. Within a period of 2 years since transitioned into Local Taxes in 2011, contributing of BPHTB tax showed a fairly good criterion contribution for Local Tax revenues in 2011 and 2012. In 2011 the percentage its contribution amounting $30.25 \%$ and in 2012 increased to $30.72 \%$.
\end{abstract}

Keywords: bphtb tax, local taxes, effectiveness, contribution 


\section{Latar Belakang}

\section{PENDAHULUAN}

Pelaksanaan otonomi daerah dimulai dengan adanya penyerahan sejumlah kewenangan (urusan) dari Pemerintah Pusat ke Pemerintah Daerah. Untuk mendukung pelaksanaan otonomi daerah, maka diperlukan sumber-sumber penerimaan daerah yang memadai dan mampu membiayai pelaksanaan pembangunan di suatu daerah. Salah satu sumber penerimaan daerah sebagaimana yang diatur dalam Undang-Undang Nomor 12 Tahun 2008 tentang Pemerintahan Daerah adalah Pajak Daerah. Pajak Daerah dapat diartikan sebagai biaya yang harus dikeluarkan seseorang atau suatu badan untuk menghasilkan pendapatan di suatu daerah, karena ketersediaan berbagai sarana dan prasarana publik yang dinikmati semua orang tidak mungkin tanpa adanya biaya yang dikeluarkan dalam bentuk pajak tersebut.

Dewasa ini, Pajak Daerah terdiri dari berbagai jenis pajak yang terkait dengan berbagai sendi kehidupan masyarakat. Salah satu jenis pajak yang dapat dipungut oleh pemerintah daerah Kabupaten/Kota sesuai UndangUndang Nomor 28 Tahun 2009 tentang Pajak Daerah dan Retribusi Daerah adalah Pajak Bea Perolehan Hak atas Tanah dan Bangunan (BPHTB). Undang-Undang Nomor 28 Tahun 2009 menyatakan bahwa Pajak Bea Perolehan Hak atas Tanah dan Bangunan (BPHTB) adalah pajak atas perolehan hak atas tanah dan/atau bangunan. Sedangkan Perolehan Hak atas Tanah dan/atau Bangunan adalah perbuatan atau peristiwa hukum yang mengakibatkan diperolehnya hak atas tanah dan/atau bangunan oleh orang pribadi atau Badan.

Pajak BPHTB semula berdasarkan Undang-Undang Nomor 21 Tahun 1997 yang kemudian diubah dengan Undang-Undang Nomor 20 Tahun 2000 tentang Bea Perolehan Hak atas Tanah dan Bangunan merupakan Pajak Pusat yang dipungut oleh pemerintah pusat melalui Direktorat Jenderal Pajak. Berdasarkan pertimbangan efisiensi dan dalam upaya menata kembali sistem perpajakan nasional yang dikaitkan dengan pelaksanaan otonomi daerah dan desentralisasi fiskal, maka dengan berlakunya Undang-Undang Nomor 28 Tahun 2009, Pajak BPHTB dialihkan menjadi pajak daerah Kabupaten/Kota. Berdasarkan Peraturan Direktorat Jendral Pajak Nomor : PER-47/PJ/2010 tertanggal 22 Oktober 2010 ditegaskan bahwa mulai tanggal 1 Januari 2011, BPHTB berubah menjadi pajak daerah. Artinya Pemerintah Kabupaten/Kota mulai tahun 2011 dapat mengelola sepenuhnya pengenaan Pajak BPHTB dan menjadikannya sebagai Pajak Daerah.

Kota Manado sebagai ibukota Provinsi Sulawesi Utara turut mengambil bagian dalam melaksanakan sistem perpajakan daerah yang sejalan dengan sistem perpajakan nasional. Potensi pajak BPHTB di Kota Manado didukung pula dengan pesatnya peningkatan kegiatan pembangunan di segala bidang dimana keperluan akan tersedianya tanah dan/atau bangunan meningkat tajam. Mengingat pentingnya tanah dan atau bangunan tersebut dalam kehidupan, maka sudah sewajarnya jika orang pribadi atau badan hukum yang mendapatkan nilai ekonomis serta manfaat dari tanah dan atau bangunan karena adanya perolehan hak atas tanah dan atau bangunan dikenakan pajak oleh pemerintah daerah. Dalam hal ini pajak yang dimaksud adalah Pajak Bea Perolehan Hak atas Tanah dan Bangunan (BPHTB).

Untuk mengukur dan menilai apakah penerimaan Pajak BPTHB di Kota Manado sudah efektif, dapat diketahui dengan melakukan analisis efektivitas. Efektivitas menunjukkan perbandingan antara output dengan tujuan. Realisasi penerimaan pajak sebagai output dan tujuannya sebagai target yang telah ditetapkan. Efektivitas pemungutan Pajak BPHTB akan berpengaruh dalam memaksimalkan penerimaan pajak BPHTB yang secara langsung memberikan kontribusi terhadap peningkatan penerimaan Pajak Daerah di Kota Manado.

\section{Tujuan Penelitian}

Tujuan penelitian ini adalah untuk menganalisa:

1. Efektivitas Pajak BPHTB yang dipungut oleh Pemerintah Kota Manado.

2. Kontribusi Pajak BPHTB terhadap penerimaan Pajak Daerah Kota Manado.

\section{Pengertian Akuntansi}

\section{TINJAUAN PUSTAKA}

Horngren dan Harison (2007: 4) mengungkapkan bahwa akuntansi adalah sistem informasi yang mengukur aktivitas bisnis, memproses data menjadi laporan dan mengkomunikasikan hasilnya kepada para pengambil keputusan. Yadiati dan Wahyudi (2006: 1) menjelaskan akuntansi adalah merupakan suatu "ilmu" yang di dalamnya berisi tentang bagaimana proses pemikiran sehingga dihasilkan suatu kerangka konseptual yang berisi tentang prinsip, standar, asumsi, dan teknik serta prosedur yang akan dijadikan landasan dalam pelaporan keuangan. Adapun Kieso, et al. (2007: 2) menyatakan bahwa karakteristik penting akuntansi adalah sebagai berikut.

1. Pengidentifikasian, pengukuran, dan pengkomunikasian, informasi keuangan tentang; 
2. Entitas ekonomi kepada;

3. Pihak yang berkepentingan.

\section{Akuntansi Perpajakan}

Muljono (2010: 2) menyatakan akuntansi pajak adalah bidang akuntansi yang berkaitan dengan perhitungan perpajakan yang mengacu pada peraturan, undang-undang dan aturan pelaksanaan perpajakan. Akuntansi pajak berfungsi mengolah data kuantitatif untuk menyajikan laporan keuangan yang memuat perhitungan perpajakan, yang kemudian akan digunakan sebagai pertimbangan pembilan keputusan.

\section{Konsep Pajak}

Pengertian atau definisi perpajakan sangat berbeda-beda, namun perbedaan tersebut pada prinsipnya mempunyai inti atau tujuan yang sama. Soemitro yang dikutip Mardiasmo (2011: 1) mengemukakan Pajak adalah iuran rakyat kepada kas negara berdasarkan undang-undang (yang dapat dipaksakan) dengan tiada mendapat jasa timbal (kontraprestasi) yang langsung dapat ditunjukan dan yang dapat digunakan untuk membayar pengeluaran umum. Siahaan (2010: 7) menjelaskan bahwa secara umum pajak adalah pungutan dari masyarakat oleh negara (pemerintah) berdasarkan undang-undang yang bersifat dapat dipaksakan dan terutang oleh yang wajib membayarnya dengan tidak mendapat prestasi kembali (kontraprestasi/balas jasa) secara langsung, yang hasilnya digunakan untuk membiayai pengeluaran negara dalam penyelenggaraan pemerintah dan pembangunan. Dalam Undang-Undang Nomor 16 Tahun 2009 tentang Ketentuan Umum dan Tata Cara Perpajakan dijelaskan bahwa pajak adalah kontribusi wajib kepada negara yang terutang oleh orang pribadi atau badan yang bersifat memaksa berdasarkan undang-undang, dengan tidak mendapatkan imbalan secara langsung dan digunakan untuk keperluan negara bagi sebesar-besarnya kemakmuran rakyat.

\section{Tujuan Pajak}

Nurksel yang dikutip Rahayu (2011: 37) mengungkapkan tujuan diberlakukannya pajak antara lain sebagai berikut.

1. Untuk mencapai kondisi meningkatnya ekonomi suatu negara

2. Untuk membatasi konsumsi dan dengan demikian mentransfer sumber dari konsumsi

3. Untuk mendorong tabungan dan menanam modal

4. Untuk mentransfer sumber dari tangan masyarakat ke tangan pemerintah sehingga memungkinkan adanya investasi pemerintah

5. Untuk memodifikasi pola investasi

6. Untuk mengurangi ketimpangan ekonomi

7. Untuk memobilisasi surplus ekonomi

\section{Fungsi Pajak}

Mardiasmo (2011: 1-2) menyatakan bahwa fungsi pajak terdiri dari dua fungsi, yaitu sebagai berikut.

1. Fungsi Budgetair (Sumber Keuangan Negara)

Pajak sebagai sumber dana bagi pemerintah untuk membiayai pengeluaran-pengeluarannya.

2. Fungsi Regularend (Pengatur)

Pajak sebagai alat untuk mengatur atau melaksanakan kebijaksanaan pemerintah dalam bidang sosial ekonomi.

\section{Sistem Pemungutan Pajak}

Mardiasmo (2011: 7) menyebutkan bahwa sistem pemungutan pajak dapat dibagi menjadi tiga, yaitu sebagai berikut.

1. Official Assessment System

2. Self Assessment System

3. With Holding System

\section{Penggolongan Jenis Pajak}

Ilyas dan Burton (2008: 29) mengungkapkan jenis pajak dapat digolongkan dalam 3 (tiga) golongan yaitu sebagai berikut.

1. Menurut Sifatnya

a. Pajak langsung, adalah pajak yang bebannya harus dipikul sendiri oleh wajib pajak dan tidak dapat dilimpahkan kepada orang lain serta dikenakan secara berulang-ulang pada waktu-waktu tertentu. 
b. Pajak tidak langsung, adalah pajak yang bebannya dapat dilimpahkan kepada orang lain dan hanya dikenakan pada hal-hal tertentu atau peristiwa-peristiwa tertentu saja.

2. Menurut Sasaran/Objeknya

a. Pajak subjektif, adalah jenis pajak yang dikenakan dengan pertama-tama memerhatikan keadaan pribadi wajib pajak (subjeknya).

b. Pajak objektif, adalah jenis pajak yang dikenakan dengan pertama-tama memerhatikan/melihat objeknya baik berupa keadaan perbuatan atau peristiwa yang menyebabkan timbulnya kewajiban membayar pajak.

3. Menurut Lembaga Pemungutnya

a. Pajak pusat, adalah jenis pajak yang dipungut oleh pemerintah pusat dan dimasukkan sebagai bagian dari penerimaan Anggaran Pendapatan dan Belanja Negara (APBN).

b. Pajak daerah, jenis pajak yang dipungut oleh pemerintah daerah dan dimasukkan sebagai bagian dari penerimaan Anggaran Pendapatan dan Belanja Daerah (APBD).

\section{Konsep Pajak Daerah}

Undang-Undang Nomor 28 Tahun 2009 tentang Pajak Daerah dan Retribusi Daerah, mendefinisikan bahwa pajak daerah yang selanjutnya disebut pajak, adalah kontribusi wajib kepada daerah yang terutang oleh orang pribadi atau badan yang bersifat memaksa berdasarkan undang-undang, dengan tidak mendapatkan imbalan secara langsung dan digunakan untuk keperluan daerah bagi sebesar-besarnya kemakmuran rakyat.

\section{Jenis dan Tarif Pajak Daerah} berikut.

Sesuai dengan Undang-Undang Nomor 28 Tahun 2009, jenis dan tarif pajak daerah antara lain sebagai

1. Jenis dan tarif Pajak Provinsi adalah sebagai berikut.

a. Pajak Kendaraan Bermotor ditetapkan paling tinggi 10\% (sepuluh persen);

b. Bea Balik Nama Kendaraan Bermotor ditetapkan paling tinggi 20\% (duapuluh persen);

c. Pajak Bahan Bakar Kendaraan Bermotor ditetapkan paling tinggi 10\% (sepuluh persen);

d. Pajak Air Permukaan ditetapkan paling tinggi 10\% (sepuluh persen);

e. Pajak Rokok ditetapkan sebesar 10\% (sepuluh persen).

2. Jenis dan tarif Pajak Kabupaten/Kota adalah sebagai berikut.

a. Pajak Hotel ditetapkan paling tinggi $10 \%$ (sepuluh persen);

b. Pajak Restoran ditetapkan paling tinggi $10 \%$ (sepuluh persen);

c. Pajak Hiburan ditetapkan paling tinggi $35 \%$ (tiga puluh lima persen);

d. Pajak Reklame ditetapkan paling tinggi 25\% (dua puluh lima persen);

e. Pajak Penerangan Jalan ditetapkan paling tinggi $10 \%$ (sepuluh persen);

f. Pajak Mineral Bukan Logam dan Batuan ditetapkan paling tinggi sebesar 25\% (dua puluh lima persen);

g. Pajak Parkir ditetapkan paling tinggi 30\% (tiga puluh persen);

h. Pajak Air Tanah ditetapkan paling tinggi sebesar 20\% (dua puluh persen);

i. Pajak Sarang Burung Walet ditetapkan paling tinggi 10\% (sepuluh persen);

j. Pajak Bumi dan Bangunan Perdesaan dan Perkotaan ditetapkan paling tinggi sebesar 0,3\% (nol koma tiga persen);

k. Bea Perolehan Hak atas Tanah dan Bangunan ditetapkan paling tinggi 5\% (lima persen).

\section{Tolak Ukur Penilaian Suatu Pajak Daerah}

Devas yang dikutip Rahayu (2011: 34) menyatakan bahwa penilaian suatu pajak daerah dapat digunakan dengan menggunakan beberapa tolak ukur antara lain sebagai berikut.

1. Hasil (Yield)

2. Keadilan (Equity)

3. Daya Guna Ekonomi (Economic Eficiency)

4. Kecocokan Sebagai Sumber Penerimaan Daerah (Suitability as a Revenue Source)

5. Kemampuan Melaksanakan (Ability to implement)

\section{Pajak Bea Perolehan Hak atas Tanah dan Bangunan (BPHTB)}

Berdasarkan Undang-Undang Nomor 28 Tahun 2009 tentang Pajak Daerah dan Retribusi Daerah, Pajak Bea Perolehan Hak atas Tanah dan Bangunan (BPHTB) adalah pajak atas perolehan hak atas tanah dan atau bangunan. Sedangkan Perolehan Hak atas Tanah dan atau Bangunan adalah perbuatan atau peristiwa hukum 
yang mengakibatkan diperolehnya hak atas tanah dan atau bangunan oleh orang pribadi atau badan. Adapun hak atas tanah dan atau bangunan adalah hak atas tanah, termasuk hak pengelolaan, beserta bangunan di atasnya, sebagaimana dimaksud dalam undang-undang di bidang pertanahan dan bangunan.

\section{Objek Pajak BPHTB}

Undang-Undang Nomor 20 Tahun 2000 tentang Bea Perolehan Hak atas Tanah dan Bangunan menjelaskan Pajak BPHTB dikenakan kepada peristiwa hukum atau perbuatan hukum atas transaksi/peralihan haknya yang meliputi pemindahan hak dan pemberian hak baru. Adapun yang menjadi objek pajak adalah perolehan hak atas tanah dan/atau bangunan, yaitu sebagai berikut.

1. Tanah, termasuk tanaman di atasnya;

2. Tanah dan bangunan;

3. Bangunan. Yang dimaksud dengan bangunan adalah konstruksi teknik yang ditanam atau diletakkan secara tetap pada tanah dan atau perairan.

\section{Subjek dan Wajib Pajak BPHTB}

Siahaan (2010: 587) menyatakan bahwa pada pengenaan Pajak BPHTB, subjek pajak dan Wajib Pajak merujuk pada diri orang atau badan yang sama, dimana subjek dan Wajib Pajak BPHTB Pajak BPHTB adalah orang pribadi atau badan yang memperoleh hak atas tanah dan atau bangunan.

\section{Dasar Pengenaan dan Tarif Pajak BPHTB}

Siahaan (2010: 588) menyatakan bahwa dasar pengenaan Pajak BPHTB adalah Nilai Perolehan Objek Pajak (NPOP). NPOP yang dimaksud terdiri atas dua, yaitu harga transaksi dan nilai pasar. Harga transaksi adalah harga yang terjadi dan telah disepakati oleh pihak-pihak yang bersangkutan. Sedangkan, nilai pasar adalah harga rata-rata dari transaksi jual beli secara wajar yang terjadi di sekitar letak tanah dan atau bangunan. Besaran Nilai Perolehan Objek Pajak Tidak Kena Pajak (NPOPTKP) ditetapkan paling rendah sebesar Rp 60.000.000,00 (enam puluh juta rupiah) untuk setiap wajib pajak. Dalam hal perolehan hak karena waris, atau hibah wasiat yang diterima orang pribadi yang masih dalam hubungan keluarga, NPOPTKP ditetapkan paling rendah sebesar Rp 300.000.000,00 (tiga ratus juta rupiah). Tarif Pajak BPHTB ditetapkan paling tinggi sebesar 5\% (lima persen) dan ditetapkan dengan peraturan daerah Kabupaten/Kota yang bersangkutan.

\section{Perhitungan Pajak BPHTB}

Siahaan (2010: 591-592) menyatakan bahwa perhitungan pajak hotel adalah sebagai berikut.

$$
\begin{aligned}
\mathrm{BPHTB} & =\text { Tarif Pajak } \mathrm{x} \text { Dasar Pengenaan Pajak } \\
& =\text { Tarif Pajak } \mathrm{x}(\mathrm{NPOP}-\text { NPOPTKP })
\end{aligned}
$$
berikut.

Apabila NPOP tidak diketahui atau lebih kecil daripada NJOP, maka perhitungan Pajak BPHTB sebagai

$$
\begin{array}{ll}
\mathrm{BPHTB} & =\text { Tarif Pajak } \mathrm{x} \text { Dasar Pengenaan Pajak } \\
& =\text { Tarif Pajak } \mathrm{x}(\mathrm{NJOP}-\mathrm{NPOPTKP})
\end{array}
$$

\section{Efektivitas Pajak BPHTB}

Mardiasmo (2009: 132) menyatakan bahwa efektivitas merupakan hubungan antara keluaran dengan tujuan atau sasaran yang harus dicapai, atau dengan kata lain efektivitas merupakan perbandingan antara input dan output. Semakin besar ouput yang dihasilkan terhadap pencapaian tujuan dan sasaran yang ditentukan, maka semakin efektif proses kerja suatu unit organisasi. Dalam penelitian ini, analisis efektivitas merupakan suatu analisa atas perbandingan realisasi penerimaan Pajak BPHTB dengan target Pajak BPHTB yang telah ditetapkan. Dengan adanya analisis ini maka akan terlihat perbedaan antara penerimaan Pajak BPHTB yang telah berjalan dengan target yang sesungguhnya telah ditetapkan oleh pemerintah daerah.

\section{Kontribusi Pajak BPHTB}

Kontribusi digunakan untuk mengetahui sejauh mana suatu jenis Pajak Daerah memberikan sumbangan dalam penerimaan Pajak Daerah dengan cara membandingkan penerimaan jenis Pajak Daerah periode tertentu dengan total penerimaan Pajak Daerah periode tertentu pula. Semakin besar hasilnya berarti semakin besar pula peranan jenis Pajak Daerah terhadap total penerimaan Pajak Daerah, begitu pula sebaliknya jika hasil perbandingannya terlalu kecil berarti peranan jenis Pajak Daerah terhadap total penerimaan Pajak Daerah juga 
kecil. (Mahmudi, 2010: 145). Dalam penelitian ini, konteks kontribusi merupakan seberapa besar sumbangan penerimaan Pajak Bea Perolehan Hak atas Tanah dan Bangunan (BPHTB) dalam pos penerimaan Pajak Daerah Kota Manado. Diharapkan dengan semakin tinggi kontribusi penerimaan Pajak BPHTB, maka akan semakin besar pula Pajak Daerah Kota Manado.

\section{Penelitian Terdahulu}

Tabel 1. Penelitian Terdahulu

\begin{tabular}{|c|c|c|c|c|c|c|}
\hline $\begin{array}{l}\text { Nama } \\
\text { Peneliti/ } \\
\text { Tahun }\end{array}$ & Judul & Tujuan & $\begin{array}{l}\text { Metode } \\
\text { Penelitian }\end{array}$ & $\begin{array}{l}\text { Hasil } \\
\text { Penelitian }\end{array}$ & Persamaan & Perbedaan \\
\hline $\begin{array}{l}\text { Fauzan dan } \\
\text { Ardiyanto } \\
(2012)\end{array}$ & $\begin{array}{l}\text { Akuntansi dan } \\
\text { Efektivitas } \\
\text { Pemungutan } \\
\text { Bea Perolehan } \\
\text { Hak atas Tanah } \\
\text { dan Bangunan } \\
\text { (BPHTB) dan } \\
\text { Kontribusinya } \\
\text { Terhadap } \\
\text { Pendapatan } \\
\text { Daerah di Kota } \\
\text { Semarang } \\
\text { Periode Tahun } \\
\text { 2008-2011 }\end{array}$ & $\begin{array}{l}\text { Bertujuan untuk } \\
\text { mengukur dan } \\
\text { mengetahui } \\
\text { tingkat } \\
\text { efektivitas } \\
\text { pemungutan } \\
\text { BPHTB dan } \\
\text { kontribusinya } \\
\text { terhadap PAD } \\
\text { Kota Semarang }\end{array}$ & $\begin{array}{l}\text { Deskriptif } \\
\text { Kuantitatif }\end{array}$ & 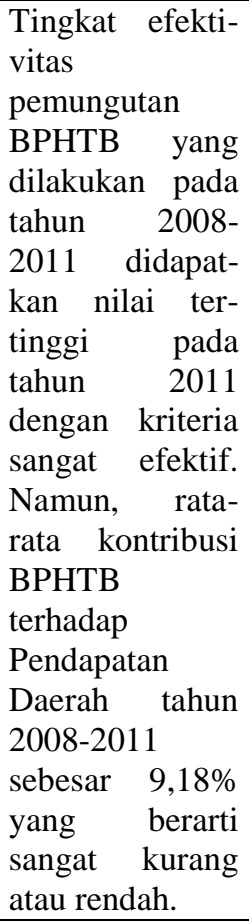 & $\begin{array}{l}\text { Peneliti } \\
\text { sebelumnya } \\
\text { melakukan } \\
\text { penelitian } \\
\text { terhadap } \\
\text { variabel yang } \\
\text { sama yaitu } \\
\text { BPHTB } \\
\text { dengan meng- } \\
\text { gunakan ana- } \\
\text { lisis rasio } \\
\text { efektivitas dan } \\
\text { rasio } \\
\text { kontribusi. }\end{array}$ & $\begin{array}{l}\text { Objek } \\
\text { penelitian } \\
\text { sebelumnya } \\
\text { berada di Kota } \\
\text { Semarang, } \\
\text { sedangkan } \\
\text { peneliti } \\
\text { mengguna-kan } \\
\text { objek } \\
\text { penelitian di } \\
\text { Kota Manado. }\end{array}$ \\
\hline $\begin{array}{l}\text { Sari } \\
(2010)\end{array}$ & $\begin{array}{l}\text { Analisis } \\
\text { Efektivitas dan } \\
\text { Kontribusi } \\
\text { Penerimaan } \\
\text { Pajak Bumi dan } \\
\text { Bangunan } \\
\text { Terhadap } \\
\text { Pendapatan } \\
\text { Daerah di Kota } \\
\text { Bandung }\end{array}$ & $\begin{array}{l}\text { Bertujuan untuk } \\
\text { mengetahui } \\
\text { efektivitas dan } \\
\text { kontribusi yang } \\
\text { diperoleh dari } \\
\text { penerimaan } \\
\text { PBB di Kota } \\
\text { Bandung }\end{array}$ & $\begin{array}{l}\text { Deskriptif } \\
\text { kuantitatif }\end{array}$ & $\begin{array}{l}\text { Pengelolaan } \\
\text { PBB pada } \\
\text { Pemkot } \\
\text { Bandung telah } \\
\text { dilaksanakan } \\
\text { secara } \\
\text { memadai. } \\
\text { Namun, } \\
\text { kontribusi yang } \\
\text { diberikan oleh } \\
\text { PBB terhadap } \\
\text { PAD masih } \\
\text { sangat kurang/ } \\
\text { rendah }\end{array}$ & $\begin{array}{l}\text { Penelitian } \\
\text { sebelumnya } \\
\text { menggunakan } \\
\text { pendekatan } \\
\text { rasio } \\
\text { efektivitas dan } \\
\text { kontribusi } \\
\text { untuk } \\
\text { mengukur } \\
\text { penerimaan } \\
\text { pajak. Hal } \\
\text { yang sama } \\
\text { juga digunakan } \\
\text { peneliti. }\end{array}$ & $\begin{array}{l}\text { Peneliti } \\
\text { sebelumnya } \\
\text { melakukan } \\
\text { penelitian } \\
\text { terhadap } \\
\text { variabel yang } \\
\text { berbeda yaitu } \\
\text { Pajak Bumi } \\
\text { dan Bangunan. }\end{array}$ \\
\hline
\end{tabular}

\section{METODE PENELITIAN}

\section{Jenis Penelitian}

Penelitian ini menggunakan jenis penelitian deskriptif dengan pendekatan kuantitatif. Penelitian deskriptif meliputi pengumpulan data untuk diuji hipotesis atau menjawab pertanyaan mengenai status terakhir dari subjek penelitian. (Kuncoro, 2009: 10). Dalam penelitian ini, peneliti akan menganalisis dengan melakukan penghitungan, pengukuran dan penilaian terhadap tingkat efektivitas dan kontribusi penerimaan Pajak Bea Perolehan Hak atas Tanah dan Bangunan (BPHTB) terhadap penerimaan Pajak Daerah di Kota Manado tahun 2011 dan 2012. 


\section{Tempat dan Waktu Penelitian}

Penelitian ini dilaksanakan pada Kantor Dinas Pendapatan Kota Manado yang bertempat di Jl. Balai Kota II Manado. Proses penelitian dilakukan pada bulan Mei 2013.

\section{Prosedur Penelitian}

Adapun prosedur yang dilakukan peneliti dalam penelitian ini adalah sebagai berikut.

1. Mengajukan Permohonan Penelitian, yaitu mengajukan permohonan penelitian dengan persetujuan fakultas untuk melakukan penelitian pada objek tersebut dan menunggu proses selanjutnya apakah diizinkan atau tidak.

2. Disposisi Pimpinan, yaitu menindaklanjuti memo atau perintah dari pimpinan ke bawahan yang menjelaskan tentang pekerjaan yang seharusnya dilaksanakan dan siapa penanggungjawabnya sesuai keinginan pimpinan sehubungan dengan adanya surat yang masuk dari luar instansi (surat permohonan penelitian yang peneliti masukkan).

3. Pengumpulan Data, yaitu melakukan pengumpulan data-data yang terkait dengan penelitian, di antaranya adalah Daftar Rincian Target dan Realisasi Penerimaan Pajak Daerah Kota Manado Tahun 2011 - 2012.

4. Analisa Data Penelitian, yaitu melakukan analisa data dengan menggunakan analisis rasio efektivitas dan rasio kontribusi yang kemudian disajikan dalam bentuk tabel dan grafik dengan menguraikan secara jelas hasil penelitian yang telah diperoleh.

5. Kesimpulan dan Saran, yaitu menarik kesimpulan dari hasil penelitian mengenai analisis efektivitas penerimaan Pajak BPHTB dan kontribusinya terhadap penerimaan Pajak Daerah, serta memberikan saransaran yang dianggap perlu.

\section{Metode Pengumpulan Data}

Kuncoro (2009: 145) menyebutkan bahwa jenis data dapat diklasifikasikan menjadi dua, yaitu sebagai berikut.

1. Data Kuantitatif, yaitu data yang diukur dalam skala numerik (angka) atau data disajikan dalam bentuk angka-angka.

2. Data Kualitatif, yaitu data yang tidak dapat diukur dalam skala numerik (angka) dan disajikan secara deskriptif.

Dalam penelitian ini sebagian besar data yang digunakan adalah data kuantitatif berupa Daftar Rincian Target dan Realisasi Penerimaan Pajak Daerah Kota Manado tahun 2011 dan 2012.

Kuncoro (2009: 148) menyatakan bahwa sumber data yang digunakan dalam penelitian umumnya ada dua, yaitu sebagai berikut.

1. Data Primer, yaitu data yang diperoleh dengan survei lapangan yang menggunakan semua metode pengumpulan data original. Dalam penelitian ini data primer yang digunakan terdiri dari hasil wawancara berupa tanya jawab langsung dengan Pejabat dan staf pegawai Dinas Pendapatan Kota Manado yang menangani pengelolaan Pajak BPHTB.

2. Data Sekunder, yaitu data yang telah dikumpulkan oleh lembaga pengumpul data dan dipublikasikan kepada masyarakat pengguna data. Data sekunder dalam penelitian ini antara lain sebagai berikut.

a. Gambaran umum objek penelitian;

b. Daftar Rincian Target dan Realisasi Penerimaan Pajak Daerah Kota Manado tahun 2011 dan 2012.

\section{Teknik Pengumpulan Data}

Teknik yang digunakan dalam penelitian ini adalah studi lapangan pada Dinas Pendapatan Kota Manado yang merupakan objek penelitian untuk mendapatkan data yang diperlukan serta peninjauan langsung ke lokasi penelitian. Dalam studi lapangan ini, penelitian dapat dilakukan dengan cara wawancara langsung yaitu dengan percakapan langsung serta tanya jawab dengan pihak Dinas Pendapatan Kota Manado dan mendapatkan data berupa Daftar Rincian Penerimaan Pajak Daerah Kota Manado tahun 2011-2012.

\section{Metode Analisis}

Kuncoro (2009: 185) menyatakan bahwa analisis data adalah proses penyederhanaan data ke dalam bentuk yang lebih mudah dibaca dan diinterpretasikan. Metode penelitian yang digunakan peneliti dalam penulisan skripsi ini adalah metode deskriptif kuantitatif dengan menerapkan analisis rasio efektivitas dan rasio kontribusi. Berdasarkan metode yang digunakan dalam penelitian ini yaitu metode deskriptif kuantitatif, maka untuk menganalisis data yang telah terkumpul, data diolah dengan menghitung data-data yang berbentuk 
kuantitatif berdasarkan analisis rasio efektivitas dan kontribusi yang kemudian dinyatakan dengan data kualitatif untuk menginterpretasikan hasil data perhitungan tersebut serta menyertai dan melengkapi gambaran yang diperoleh dari analisis data kualitatif untuk memecahkan masalah yang diteliti yang akhirnya akan menarik kesimpulan dari pengolahan data tersebut. berikut.

Adapun tahapan-tahapan yang dilakukan peneliti dalam melakukan analisis data antara lain sebagai

1. Menyusun tabel target dan realisasi penerimaan Pajak Daerah dari Dinas Pendapatan Kota Manado tahun 2011 dan 2012.

2. Menyusun tabel analisis efektivitas penerimaan Pajak BPHTB dengan rumus sebagai berikut.

Dengan kriteria efektivitas sebagai berikut.

Tabel 2. Interpretasi Nilai Efektivitas

\begin{tabular}{|l|l|}
\hline Persentase & Kriteria \\
\hline$>100 \%$ & Sangat Efektif \\
\hline $90-100 \%$ & Efektif \\
\hline $80-90 \%$ & Cukup Efektif \\
\hline $60-80 \%$ & Kurang Efektif \\
\hline$<60 \%$ & Tidak Efektif \\
\hline
\end{tabular}

Sumber: Depdagri, Kepmendagri No. 690.900.327 tahun 1996 (Halim, dikutip dalam Sari, 2010)

3. Menyusun tabel analisis kontribusi realisasi penerimaan Pajak BPHTB terhadap penerimaan Pajak Daerah. Analisis kontribusi adalah suatu alat analisis yang digunakan untuk mengetahui seberapa besar kontribusi yang dapat disumbangkan dari penerimaan Pajak BPHTB terhadap penerimaan Pajak Daerah di Kota Manado dengan cara membandingkan antara realisasi penerimaan Pajak BPHTB terhadap penerimaan Pajak Daerah, dengan rumus sebagai berikut.

Dengan asumsi sebagai berikut.

Tabel 3. Klasifikasi Kriteria Kontribusi

\begin{tabular}{|l|l|}
\hline Persentase & Kriteria \\
\hline $0,00 \%-10 \%$ & Sangat Kurang \\
\hline $10,10 \%-20 \%$ & Kurang \\
\hline $20,10 \%-30 \%$ & Sedang \\
\hline $30,10 \%-40 \%$ & Cukup Baik \\
\hline $40,10 \%-50 \%$ & Baik \\
\hline Di atas 50\% & Sangat Baik \\
\hline
\end{tabular}

Sumber: Tim Litbang Depdagri - Fisipol UGM 1991 (Halim, dikutip dalam Sari, 2010)

4. Membandingkan hasil yang diperoleh dengan teori yang ada.

5. Penarikan kesimpulan dari hasil penelitian dan memberikan saran-saran yang dianggap perlu. 
Hasil Penelitian

\section{HASIL PENELITIAN DAN PEMBAHASAN}

Laporan Target dan Realisasi Penerimaan Pajak Daerah Kota Manado

Tabel 4. Target dan Realisasi Penerimaan Pajak Daerah Kota Manado Tahun Anggaran 2011 dan 2012

\begin{tabular}{|c|c|c|c|c|c|}
\hline \multirow[t]{2}{*}{ No. } & \multirow[t]{2}{*}{ Jenis Pajak Daerah } & \multicolumn{2}{|c|}{ Tahun 2011 (Rupiah) } & \multicolumn{2}{|c|}{ Tahun 2012 (Rupiah) } \\
\hline & & Target & Realisasi & Target & Realisasi \\
\hline 1. & Pajak Hotel & 12.063 .820 .000 & 10.424 .824 .091 & 14.170 .223 .000 & 14.385 .737 .651 \\
\hline 2. & Pajak Restoran & 27.292 .000 .000 & 26.715 .829 .539 & 32.918 .172 .500 & 35.362 .827 .656 \\
\hline 3 . & Pajak Hiburan & 4.250 .000 .000 & 3.389 .256 .027 & 5.400 .000 .000 & 5.498 .904 .721 \\
\hline 4. & Pajak Reklame & 3.649.987.500 & 2.334.703.597 & 4.200.000.000 & 2.760 .872 .514 \\
\hline \multirow[t]{2}{*}{5.} & Pajak Mineral Bukan & & & & \\
\hline & Logam Dan Batuan & 150.012 .000 & 49.391 .634 & 100.000 .000 & 12.490 .678 \\
\hline 6. & Pajak Parkir & 2.000 .000 .000 & 1.784 .533 .037 & 2.100 .000 .000 & 3.273 .738 .607 \\
\hline 7. & Pajak Air Tanah & 80.000 .000 & 9.719 .800 & 500.000 .000 & 457.154 .778 \\
\hline 8. & Pajak Burung Walet & 7.500 .000 & - & 20.000 .000 & - \\
\hline 9. & Pajak ВРHTB & 42.500 .000 .000 & 30.169 .578 .345 & 35.781 .001 .690 & 41.846.497.614 \\
\hline \multirow[t]{2}{*}{10.} & Pajak Penerangan Jalan & 30.000 .000 .000 & 24.855 .630 .304 & 32.612 .449 .465 & 32.628 .188 .165 \\
\hline & Total & 121.993 .319 .500 & 99.733 .466 .374 & 127.801 .846 .655 & 136.226 .412 .384 \\
\hline
\end{tabular}

Sumber: Dinas Pendapatan Kota Manado, 2013

Pada tabel di atas terlihat jelas bahwa realisasi Pajak BPHTB dalam dua tahun terakhir yakni tahun 2011 - 2012 sangat mendominasi tingkat realisasi penerimaan Pajak Daerah Kota Manado. Walaupun baru menjadi Pajak Daerah, namun secara nominal penerimaan Pajak BPHTB dapat melampaui penerimaan jenis Pajak Daerah lainnya yang dikelola Pemerintah Kota Manado.

\section{Pembahasan}

Analisis Efektivitas Penerimaan Pajak BPHTB Kota Manado

Berikut ini perhitungan efektivitas penerimaan Pajak BPHTB Kota Manado tahun anggaran 2011 dan 2012.

1. Efektivitas Tahun $2011=\longrightarrow$ x $100 \%=70,99 \%$

2. Efektivitas Tahun $2012=\longrightarrow$ - $100 \%=116,95 \%$

Tabel 5. Efektivitas Penerimaan Pajak BPHTB Kota Manado Tahun Anggaran 2011 dan 2012

\begin{tabular}{|l|l|l|l|l|}
\hline Tahun Anggaran & $\begin{array}{l}\text { Target Pajak } \\
\text { BPHTB (Rupiah) }\end{array}$ & $\begin{array}{l}\text { Realisasi Pajak } \\
\text { BPHTB (Rupiah) }\end{array}$ & $\begin{array}{l}\text { Persentase } \\
(\boldsymbol{\%})\end{array}$ & Kriteria \\
\hline 2011 & 42.500 .000 .000 & 30.169 .578 .345 & 70,99 & Cukup Efektif \\
\hline 2012 & 35.781 .001 .690 & 41.846 .497 .614 & 116,95 & Sangat Efektif \\
\hline
\end{tabular}

Sumber: Hasil Pengolahan Data, 2013

Dari tabel di atas dapat dilihat untuk tahun 2011 tingkat efektivitas penerimaan pajak BPHTB Kota Manado sebesar 70,99\%. Untuk tahun 2012 tingkat efektivitas penerimaan Pajak BPHTB Kota Manado sebesar $116,95 \%$, naik $45,96 \%$ dari tahun sebelumnya. Sesuai dengan tabel di atas bahwa pada tahun 2011 realisasi penerimaan Pajak BPHTB belum mencapai target dengan kriteria "Cukup Efektif" yakni sebesar 70,99\%, sedangkan pada tahun 2012, realisasi penerimaan Pajak BPHTB sudah melebihi target dengan kriteria "Sangat Efektif" yakni sebesar 116,95\%. Dari data ini dapat dilihat bahwa dalam tahun 2011 - 2012 terjadi peningkatan realisasi penerimaan Pajak BPHTB di Kota Manado. Hasil analisis efektivitas penerimaan Pajak BPHTB tahun 2012 menunjukkan bahwa Dinas Pendapatan Kota Manado telah berhasil dalam merealisasikan Pajak BPHTB lebih dari target yang ditentukan.

\section{Analisis Kontribusi Pajak BPHTB Terhadap Penerimaan Pajak Daerah Kota Manado}

Adapun cara perhitungan kontribusi Pajak BPHTB terhadap penerimaan Pajak Daerah Kota Manado tahun anggaran 2011 dan 2012 sebagai berikut.

1. Kontribusi Tahun $2011=-\times 100 \%=30,35 \%$ 
Tabel 6. Kontribusi Pajak BPHTB Terhadap Penerimaan Pajak Daerah Kota Manado Tahun Anggaran 2011 dan 2012

\begin{tabular}{|l|l|l|l|l|}
\hline Tahun Anggaran & $\begin{array}{l}\text { Realisasi Pajak } \\
\text { BPHTB (Rupiah) }\end{array}$ & $\begin{array}{l}\text { Realisasi Pajak } \\
\text { Daerah (Rupiah) }\end{array}$ & $\begin{array}{l}\text { Kontribusi } \\
(\boldsymbol{\%})\end{array}$ & Kriteria \\
\hline 2011 & 30.169 .578 .345 & 99.733 .466 .374 & 30,25 & Cukup Baik \\
\hline 2012 & 41.846 .497 .614 & 136.226 .412 .384 & 30,72 & Cukup Baik \\
\hline
\end{tabular}

Sumber: Hasil Pengolahan Data, 2013

Dari tabel di atas, realisasi penerimaan Pajak BPHTB untuk tahun 2011 sebesar Rp. 30.169.578.345 dengan persentase kontribusinya 30,25\% dan tahun 2012 sebesar Rp. 41.846.497.614 dengan persentase kontribusinya $30,72 \%$. Hasil tersebut didapat berdasarkan perhitungan kontribusi Pajak BPHTB terhadap realisasi penerimaan Pajak Daerah Kota Manado. Dari hasil analisis ini diketahui bahwa kontribusi Pajak BPHTB masuk dalam kriteria "Cukup Baik" dengan sumbangan terbesar terhadap penerimaan Pajak Daerah terjadi pada tahun 2012 yaitu sebesar 30,72\% dan yang terendah pada tahun 2011 yang hanya sebesar 30,25\%. Pada sepanjang tahun 2011 sampai dengan tahun 2012 ada peningkatan realisasi penerimaan Pajak BPHTB sebesar Rp. 11.676.919.269 dengan persentase 0,47\%. Peningkatan kontribusi tersebut diperoleh dengan cara membandingkan jumlah nominal dan persentase kontribusi setiap tahunnya, yaitu dari tahun $2011-2012$. Dengan demikian dapat diketahui perkembangan penerimaan Pajak BPHTB pada Dinas Pendapatan Kota Manado.

\section{Kesimpulan}

\section{PENUTUP}

Berdasarkan hasil penelitian, maka diambil kesimpulan sebagai berikut.

1. Dari hasil uji efektivitas penerimaan Pajak BPHTB di Kota Manado pada tahun 2011, realisasi Pajak BPHTB belum mencapai target dengan persentase 70,99\% dan pada tahun 2012 sudah melampaui target dengan persentase $116,95 \%$. Sesuai dengan kriteria yang digunakan, maka tingkat efektivitas penerimaan Pajak BPHTB tahun 2011 masih tergolong cukup efektif, sedangkan pada tahun 2012 sudah sangat efektif karena telah mencapai persentase lebih dari $100 \%$.

2. Secara keseluruhan penerimaan Pajak BPHTB sudah memberikan kontribusi yang cukup baik terhadap penerimaan Pajak Daerah Kota Manado tahun 2011 dan 2012 sehingga dapat mempengaruhi jumlah Pajak Daerah yang diterima. Untuk tahun 2011 persentase kontribusinya sebesar 30,25\% dan tahun 2012 sebesar $30,72 \%$. Walaupun persentase kenaikan hanya mencapai $0,47 \%$, namun secara nominal mengalami kenaikan yang signifikan.

3. Sesuai dengan laporan realisasi penerimaan Pajak Daerah Kota Manado Tahun 2011 dan 2012, realisasi penerimaan Pajak BPHTB merupakan pos paling dominan di antara jenis pajak lainnya dalam struktur penerimaan Pajak Daerah Kota Manado. Meski baru dua tahun dipungut oleh Pemerintah Kota, namun hasil penerimaan Pajak BPHTB sudah mengungguli hasil penerimaan jenis Pajak Daerah lainnya.

\section{Saran}

Saran yang dapat diberikan penulis sebagai berikut.

1. Pemerintah Daerah dalam hal ini Dinas Pendapatan Kota Manado perlu melakukan perhitungan potensi, target dan penerimaan secara dinamis dari waktu ke waktu. Mengingat potensi Pajak BPHTB senantiasa berkembang seiring dengan perkembangan perekonomian daerah, maka target Pajak BPHTB untuk tahuntahun berikutnya perlu dinaikan.

2. Perlu adanya koordinasi antara pihak-pihak terkait dalam pemungutan Pajak Bea Perolehan Hak atas Tanah dan Bangunan (BPHTB), yang dalam hal ini adalah Dinas Pendapatan Daerah, Notaris/Pejabat Pembuat Akta Tanah (PPAT) dan Badan Pertanahan Nasional (BPN) untuk mensosialisasikan kepada masyarakat tentang peran sertanya dalam pembayaran Pajak BPHTB, sehingga dengan demikian penerimaan daerah dari Pajak BPHTB akan semakin meningkat. 


\section{DAFTAR PUSTAKA}

Fauzan, Muhammad., Ardiyanto, Didik M. 2012. Akuntansi dan Efektivitas Pemungutan Bea Perolehan Hak atas Tanah dan Bangunan (BPHTB) dan Kontribusinya Terhadap Pendapatan Daerah di Kota Semarang Periode Tahun 2008-2011. Jurnal. Volume 1. No. 2. Universitas Diponegoro. Semarang.

Horngren., Harison. 2007. Akuntansi. Erlangga. Jakarta.

Ilyas, Wirawan B., Burton, Richard. 2008. Hukum Pajak Edisi 4. Salemba Empat. Jakarta.

Kieso, D., Weygandt, J., Warfield, T. 2007. Akuntansi Intermediate. Edisi Keduabelas. Jilid 1. Erlangga. Jakarta.

Kuncoro, Mudrajad. 2009. Metode Riset untuk Bisnis \& Ekonomi. Edisi 3. Erlangga. Jakarta.

Mahmudi. 2010. Analisis Laporan Keuangan Pemerintah Daerah. Sekolah Tinggi Ilmu Manajemen. Yogyakarta.

Mardiasmo. 2009. Akuntansi Sektor Publik. Andi. Yogyakarta.

Mardiasmo. 2011. Perpajakan. Edisi Revisi 2011. Andi. Yogyakarta.

Muljono, Djoko. 2010. Panduan Brevet Pajak, Akuntansi Pajak dan Ketentuan Umum Perpajakan. Andi. Yogyakarta.

Rahayu, Betty. 2011. Analisis Potensi Pajak Hotel Terhadap Realisasi Penerimaan Pajak Hotel di Kabupaten Garut. Skripsi. Universitas Diponegoro. Semarang.

Republik Indonesia. Undang-Undang Nomor 20 Tahun 2000 Tentang Perubahan atas Undang-Undang Nomor 21 Tahun 1997 Tentang Bea Perolehan Hak atas Tanah dan Bangunan. Jakarta.

Republik Indonesia. Undang-Undang Nomor 12 Tahun 2008 Tentang Pemerintahan Daerah. Jakarta.

Republik Indonesia. Undang-Undang Nomor 16 Tahun 2009 Tentang Ketentuan Umum dan Tata Cara Perpajakan. Jakarta.

Republik Indonesia. Undang-Undang Nomor 28 Tahun 2009 Tentang Pajak Daerah dan Retribusi Daerah. Jakarta.

Sari, Anggara Yulia. 2010. Analisis Efektivitas dan Kontribusi Penerimaan Pajak Bumi dan Bangunan Terhadap Pendapatan Daerah di Kota Bandung. Jurnal. Volume 13. No. 2. Universitas Pendidikan Indonesia. Bandung.

Siahaan, Marihot P. 2010. Pajak Daerah dan Retribusi Daerah. Edisi Revisi. PT. Raja Grafindo Persada. Jakarta.

Yadiati, Winwin., Wahyudi, Ilham. 2006. Pengantar Akuntansi. Kencana. Jakarta. 